\title{
Enter the middleman: legitimisation of literary agents in the British Victorian publishing industry 1875-1900
}

Article

Accepted Version

Joseph, M. (2020) Enter the middleman: legitimisation of literary agents in the British Victorian publishing industry 18751900. Business History, 62 (6). pp. 940-959. ISSN 1743-7938 doi: https://doi.org/10.1080/00076791.2018.1514013 Available at https://centaur.reading.ac.uk/75265/

It is advisable to refer to the publisher's version if you intend to cite from the work. See Guidance on citing.

To link to this article DOI: http://dx.doi.org/10.1080/00076791.2018.1514013

Publisher: Taylor \& Francis

All outputs in CentAUR are protected by Intellectual Property Rights law, including copyright law. Copyright and IPR is retained by the creators or other copyright holders. Terms and conditions for use of this material are defined in the End User Agreement.

www.reading.ac.uk/centaur

\section{CentAUR}


Central Archive at the University of Reading

Reading's research outputs online 


\title{
Enter the Middleman:
}

\section{Legitimisation of Literary Agents in the British Victorian Publishing Industry \\ 1875-1900}

\begin{abstract}
The literary agent is a recent addition to the publishing industry, yet in a relatively short space of time has become instrumental in the production of literature. This paper examines the origins and development of the A. P. Watt Literary Agency to explore how it became a dominant organization in the late nineteenth century. The paper analyses how its founder Alexander Pollock Watt despite being met with resistance, gained legitimacy to be accepted by authors and publishers. Through an analysis of historical sources this paper argues that by using contract law, Watt was able to disrupt existing business practices.
\end{abstract}

Keywords: Nineteenth century, literary agents, publishing, institutional theory, contract law, creative industries, Britain

Word Count: 10,998 


\section{Enter the Middleman:}

\section{Legitimation of Literary Agents in the British Victorian Publishing Industry}

1875-1900

\section{Introduction}

The creative industries (primarily broadcasting, publishing, performing arts, music and film) in recent decades have become more complex. In conjunction, the significance of the functions that mediate between the pool of organizations in these creative industries has increased (Caves 2002; Hesmondhalgh 2013; Kung 2014; Bilton 2017). One of the most notable changes has been the importance of mediators in the value chain of producing creative products, which in the context of this paper are agents (Caves 2002). Agents provide a link between the talent, whether that be a television presenter, author or actor and the organizations responsible for turning creative products into tangible commodities. They also act as gatekeepers, cultural producers and influencers, as they often choose which creative products are available in the marketplace. In the context of the publishing industry - the sector on which this paper is based - although literary or author's agents are the most recent addition to the value chain of producing literature, little is understood in a business context as to why they now have a significant position.

Literary agents who provide a link between authors and publishers in exchange usually for ten per cent commission, emerged in the mid-nineteenth century. Initially, literary agents were not welcomed by some, referred to as 'unscrupulous opportunists' seeking to upset the dynamics of the Victorian publishing industry (Heinemann 1893: 663). However, within a short space of time, agents progressed from being considered as outsiders to a key function of the production of literature. This paper traces the origins of how the literary agency entered the publishing industry, in particular the processes that Alexander Pollock (A. P.) Watt (1834 1914) used in order to establish a business that endured for over a century (Rubinstein 1975). 
Although not the first, Watt is considered the most notable agent as he was instrumental in professionalising the relationship between authors and publishers, despite in some instances being met with fierce resistance. This raises the question as to why was Watt successful in disrupting accepted and legitimised business practices within an industry that was firmly rooted in traditional business practices? Prompting a further question: how did the A. P. Watt literary agency itself become legitimate in the Victorian publishing industry despite being met with resistance?

Using institutional theory, this paper will explore the mechanisms and processes that enabled Watt's literary agency and literary agents in general to become accepted in the publishing industry. The rise of the literary agent has been widely chronicled in research on the publishing industry (Hepburn 1968; Feather 2006; Gillies 2007; Finkelstein and McCleery 2013; Cottenet 2017). Most studies concentrate on what literary agents did once they were established. Although, this paper argues that further analysis is needed to highlight how literary agents developed to become dominant organizations in the British publishing industry today. Furthermore, the literary agent has not been widely discussed from a business perspective, more specifically within business history which can be an insightful approach for exploring how agents entered the field and their subsequent effect on the contemporary publishing industry. The paper begins with a discussion of legitimacy in organizations, followed by an explanation of the sources used. The paper then explores the historical context which provided the opportunities for literary agents to gain a foothold in the industry, followed by an explanation of how Watt gained legitimacy by using contract law to professionalise and formalise transactions between himself, authors and publishers.

\section{Legitimacy Building in Organizations}


The conversation surrounding organizational legitimacy has been a focal point of institutional theory over the past few decades, (Meyer and Rowan 1977; DiMaggio and Powell 1983; North 1990; Aldrich and Fiol 1994; Suddaby and Greenwood 2005; Battilana, Leca et al. 2009; Deephouse and Suchman 2013; Hampel and Tracey 2016). Much of the research in this area as pointed out by Marquis and Raynard (2015) offers insights into how social actors instigate broad institutional change at the field level. They argue that more attention should be paid to how 'organizations strategically shape their institutional contexts to further their own individual ends' (Marquis and Raynard 2015: 295). In addition, Suddaby and Viale (2011) point out that a central problem in institutional theory is its inability to explain processes of institutional change. Therefore, going back 'inside' the organization to explore why practices appear to become legitimate allows for research to address in more detail the relationship between the decisions taken by individuals, organizations and how elements of the institutional context in which they are embedded are manifested inside organizations (Suddaby, Elsbach et al. 2010).

Generally legitimacy is understood as 'desirable, proper and appropriate actions within some socially constructed system of norms, values, beliefs and definitions (Suchman 1995: 574). Deephouse and Suchman (2013) and Suddaby and Greenwood (2005) comment that there has been considerable research undertaken on the processes of legitimacy but not enough attention has been paid to 'understanding how it is acquired, maintained and lost' (Suddaby and Greenwood 2005: 37). Some institutional theorists argue that a mechanism of gaining legitimacy is by the adoption of legitimate structures, practices and symbols (Aldrich and Fiol 1994; Suddaby, Bitektine et al. 2017: 452) or what Suchman (1995: 589) refers to as 'formalisation;' codifying informal procedures and bringing them under official control. Drawing on the approach of mimetic isomorphism (DiMaggio and Powell 1983), Deephouse and Suchman (2013) propose that a source of legitimacy is by a practice generating numerous 
adopters. They identify 'interorganizational relations' as a key mechanism, as one organization gaining legitimacy fosters legitimacy in another. The challenge is then for new entrants to be 'approved' by established and legitimate organizations. The point at which approval is given is crucial as it allows the new entrants to be perceived as legitimate within the field, especially within old sectors (Suchman 1995).

Analysing how A. P. Watt and his literary agency gained legitimacy in the nineteenth century publishing industry, brings to the foreground how multiple processes are used at varying stages of building new rules and processes in an institutional field, demonstrating how legitimation can be a complex and multi layered phenomenon (Suddaby, Bitektine et al. 2017). Deephouse, Bundy et al. (2018) propose that legitimacy should be considered as a dynamic process that is continually changing. Different types of legitimation activities are used by change agents at different points in time, and the type of activity used is dependent on the situation. Deephouse, Bundy et al. (2018: 43) introduce what they refer to as a new scenario in institutional theory, which focuses on the strategic creation of new institutions by institutional entrepreneurs; a process they refer to as being 'institutionally innovating.' They discuss that it is separate from only gaining legitimacy because the actions required to create new institutional rules and norms are different from demonstrating appropriateness of a new instance of an already familiar form within a stable institutional regime. This approach is useful for exploring the case of Watt as literary agencies were not wide spread at the time.

The structure of the publishing industry in the nineteenth century had ensued for generations therefore could be considered as a stable institutional environment. Therefore, Watt needed to be institutionally innovative to gain legitimacy in three scenarios. Firstly, as a literary agent to authors, secondly to be recognised as a formal representative of authors to publishers, and thirdly the literary agency itself as an independent organization to the publishing industry needed to be considered legitimate. Watt initially required authors to be legitimacy evaluators. 
These are defined as actors (whether individuals or collectives) who make judgements regarding the social properties of an organization, and through their actions confer legitimacy (Bitektine and Haack 2015). The social judgement and acceptance of Watt by authors as a collective would consequently influence publishers to also confer legitimacy. In addition, as argued by Caves (2002) and Gillies (2007) in her comprehensive monograph on the development of literary agents, the agent also served publishers as they aided them in finding new manuscripts to commission. Consequently, Watt was required to be perceived as legitimate by both parties therefore needed to use different legitimation processes to satisfy their varying needs. The empirical sections of this paper follow the trajectory of this process, firstly exploring how Watt gained legitimacy with authors before discussing the mechanisms he used to gain further legitimacy with publishers.

Suddaby, Bitektine et al. (2017: 451) discuss that further research should be conducted which demonstrates which social actors are 'engaged in measuring, producing or evaluating legitimacy.' Analysing how authors and publishers conferred legitimacy to Watt and the literary agency brings to the foreground the processes of how legitimacy was gained, understood and appropriated between these sets of actors. Drawing on Biketine and Haack's (2015) definition of legitimacy evaluators, the paper provides an analysis of the social actors engaged in producing legitimacy, contributing to the growing area of research which addresses microfoundations of organizational processes in institutional research (Powell and Colyvas 2008; Micelotta, Lounsbury et al. 2017).

Castelló, Etter et al. (2016) discuss that organizations make strategic choices in order to affect the amount and type of legitimacy they possess, and strategic targets can be manipulated to benefit an organization. They argue that the significance of power relations between actors who have control of the legitimacy process is underestimated in research. There is a need to identify and engage with the holder(s) of collective or central authority over 
legitimation which in this context would be authors and publishers. Watt's actions could be considered as strategic manipulation, as the mechanisms he uses to gain authority and legitimacy are an attempt to create consistency between his new agency and the wider publishing industry. Watt needed legitimacy from authors to act on their behalf, and publishers needed to see evidence of legitimacy being conferred to accept literary agents. As shall be discussed later in this paper, Watt strategically used contract law to provide him with sufficient authority in negotiations, consequently exemplifying the appropriateness of the new norms he was creating to the institutionally stable environment of the publishing industry.

From an economic theory perspective, Caves (2002) identifies that contracts are the defining factors at the intersection between art and commerce, and Watt's use of contracts was a defining juncture that aided him in gaining legitimacy. Assenova \& Sorenson (2017: 804) argue that possessing legal status commonly serves as an 'attribute used to assess sociopolitical legitimacy,' which provides a level of appropriateness to the activities of an organization. As a formal and socially accepted structure, the legal system allowed Watt to overcome some resistance from legitimate organizations, destabilising the formal interorganizational relationships between authors and publishers. This paper argues it was Watt's use of contract law to broker power between himself as the newcomer, with authors and publishers who held the collective power of legitimation. Exploring Watt as a change agent and his use of contract law as a purposive effort to initiate change, contributes to other studies which address legitimacy building in organizations (Lawrence, Suddaby et al. 2011; Hampel and Tracey 2016).

Caves (2002) discusses that the growth of the literary marketplace in the nineteenth century provided an opportunity for literary agents. They provided a job-matching or 'matchmaking' function between authors and other publishing businesses including the newspaper press (Caves 2002: 67). The origin of their role Caves (2002) argues is the 
underlying reason why the agent today has an efficient gatekeeping function in the creative industries. Watt manoeuvred his way from being at the periphery of the publishing industry into an important position. He carefully selected the authors he chose to represent, and subsequently chose which editors and houses were in receipt of literary products. Therefore, both authors and manuscripts went through a type of funnelling process which was constructed around the literary agency. Caves (2002) points out it is not clear as to when agents were no longer shunned in the industry, yet by exploring the process of how Watt and his literary agency gained legitimacy this paper demonstrates the turning point for this literary business.

The history of the literary agent has been chronicled in research on book history and the history of the publishing industry, and the practices put forward by Watt are discussed in detail (Hepburn 1968; Gillies 1993; Gillies 2007). However these studies have neglected an indepth analysis of why literary agents became accepted, considering that publishing was a conservative industry built on centuries of gentlemanly tradition (Sutherland 2013). A historical approach to understanding the processes of institutional change in organizations is beneficial as it allows for an insight into the roles that individuals play in institutional processes (Suddaby, Foster et al. 2014; Decker, Üsdiken et al. 2018). In particular, legitimacy building in an organizational field can play an important role in understanding the construction of institutional processes, as new entrants to an industry seek to establish fit between the organization and the cultural values of the wider social environment (Bitektine and Haack 2015; Suddaby, Bitektine et al. 2017).

Being perceived as legitimate is a 'critical attribute of successful organizations,' and tracing the interplay between organizations and their institutional environment, whilst identifying the point at which legitimacy is achieved can further our understanding of institutional behaviour in organizational fields (Seppälä 2017: 1). This paper utilises the approach of institutional theory and historical sources to address the gaps in the research on 
the history of the literary agent. Subsequently addressing Caves (2002) comments which highlight the lack of research as to why agents hold such a pivotal position in contemporary creative industries. The approach of how sources are used in this paper is detailed in the next section.

\section{Historical Sources}

Much research has been undertaken which explores how institutionalised structures and practices move through time and space, yet there is scope for further work to be undertaken to address why structures appear to be legitimate and how broader elements of the wider social context are manifested inside organizations (Suddaby, Elsbach et al. 2010). Drawing on this conversation, Maclean, Harvey et al (2016: 610) comment that organization studies desires to understand how individuals fashion organizational structures and practices that frame societal relations and institutions, yet the field to date has been limited by 'contemporary, crosssectional studies' that cover limited time spans. Historical approaches to organization studies can provide new insights into the formation of what Suddaby (2010) refers to as the 'institutional story' of fields, what Maclean, Harvey et al. (2016) comment has the potential to reveal transformative social processes. Analysing social actors and organizations in their historical context provides meaning that may not be observed in a contemporary setting, whereas a historical approach 'emphasises temporally contextualised explanations of organizations' (Wadhwani and Bucheli 2013: 4).

The A. P. Watt literary agency was founded circa. 1875. A contentious date as it is unclear as to when Watt embarked on transitioning from being an advertising to a literary agent, however the firm celebrated it's centenary in 1975 (Hepburn 1968; Rubinstein 1975; Gillies 2007). Until its acquisition by United Agents in 2012, the A. P. Watt literary agency was considered to be the oldest in Britain (Rubinstein 1975). It held a dominant place in the 
industry, and is revered for representing some of literatures leading authors, both past and present (Cottenet 2017). Exploring the construction of such a dominant organization and its subsequent influence on an industry brings further insights into how businesses that operate with what is now referred to as intellectual property developed, as they are a key part of the current economic climate in the UK (Howkins 2013; DCMS 2016; DCMS and Bradley 2017). As this paper is concerned with exploring mechanisms used to acquire legitimacy, narrative sources such as letters which presented evidence of choices by Watt are deemed particularly important, as these sources highlighted patterns of strategic change and the motivations for his choices. Letter writing was the main mode of communication between what I refer to as literary businesses (authors, publishers, literary agents and editors) in the nineteenth century, and fortunately much of these letters are either published or held in publicly accessible archives. The sources used in this paper are referenced from the business archives of the A. P. Watt literary agency, which is shared between the University of North Carolina (UNC) and the Berg Collection housed at the New York Public Library; a handful of papers are also stored at Columbia University. ${ }^{1}$

I intended to consult the earliest documents of the A. P. Watt literary agency, however as explained to me by the archivist at the Berg Collection, the first four letter books created by Watt had been lost; these would have accounted for Watt's personal and business letters written roughly at the same time that he started his agency. Fortunately, there was still an abundance of letters in later books that I was able to view which confirmed how Watt operated his business in its infancy; therefore, the missing books were not too detrimental to this research. As I am taking a qualitative and interpretative approach, quantitative sources such as account books and royalty ledgers were not consulted.

\footnotetext{
${ }^{1}$ Abbreviated citations for historical sources are used in footnotes throughout the paper, the full reference of the holding archives are detailed in the reference list.
} 
Drawing on business letters and contracts allows for an exploration of how different mechanisms were used for Watt to be perceived as legitimate and thus connecting his movement to later developments in the field can highlight the foundations of how institutional change took root. I also draw on published newspaper articles which provides an opportunity to understand change from the perspective of those outside the organization on which this disruptive change had a direct effect. These articles are coloured by the intended message to the audience yet analysing these items in conjunction with letters and contracts that are less open to re-interpretation or subjective distortion (Alvesson and Sköldberg 2009), provides a fuller picture of institutional change. Consequently, this enriches the understanding of the institutional context in which letters written by Watt were produced, (Kipping, Wadhwani et al. 2013). The subsequent sections address the institutional context of the Victorian publishing industry in relation to the mechanisms that Watt used to disrupt legitimised practices, creating new ways of doing business that have survived for over century.

\section{The Open Window: Opportunities for a Literary Middleman}

In 1896, Sir Walter Besant (1836-1901), one of the founders of the Society of Authors, wrote the foreword for a collection of letters written to the A. P. Watt literary agency by satisfied clients. This includes a comprehensive account of what the literary agent initially did. Besant wrote:

\footnotetext{
'The work of The Literary Agent is to conduct all business arrangements of every kind for Authors and Playwrights; that is to say, to place MSS [manuscripts] to the best advantage; to watch for openings; to sell Copyrights, either absolutely or for a limited period, to collect Royalties, and to receive other moneys due; to transfer
} 
Literary Property; to value Literary Property; to obtain opinions to MSS, etc. etc.' (Watt 1896: xi).

This description was written with one person in mind, Alexander Pollock Watt, who is regarded by most book historians as the most notable literary agent in Victorian Britain (Hepburn 1968; Feather 2006; Gillies 2007; Cottenet 2017). He started his agency circa Initially, an agent was defined as a person who purchased books on behalf of a bookseller, the term was then applied to the role of literary advisors to authors and publishers, and finally to the definition as applied in the late nineteenth century.

Although by the 1900s the literary agent was a well-known and accepted figure in the publishing industry, the window of opportunity for a literary middleman had been slow to emerge. The role of the literary agent is a development of the informal relationship between authors and the functional role of the author's reader (Finkelstein and McCleery 2013). These individuals were often friends who worked in some capacity with literature, offering critique on how manuscripts could be improved before they were sent to publishers and editors to increase acceptance. John Forster (1812-1876) was one of the most well-known readers in the mid-nineteenth century. Forster has been described as Charles Dickens's (1812-1870) unofficial or informal literary agent, negotiating contracts with publishers on Dickens's behalf; he also held power of attorney when Dickens visited America in 1867 (Davies 1983; Eliot 2012). Furthermore, Sir Walter Scott (1771-1832), who was one of the most popular novelists at the turn of the nineteenth century, made use of his business partner and friend James Ballantyne (1772-1833) to check over his work and tout to different publishers, including Archibald Constable (1774-1827) and the House of Longman (Scott 1831; Fowler Wright 2012). 
Yet by the late nineteenth century, this previously informal relationship between author and friend/advisor became professionalised, an occurrence that could be argued as a direct consequence of the progression and professionalisation of authorship, which is defined here as the occupation of writing for publication. Professional authors do not write solely as a hobby. The eighteenth century saw the condition of the professional author - referred to as the author for short - improve as it became more accessible to create a living from their writing, and furthermore authors were able to pursue the profession more easily than in previous centuries (Hepburn 1968; Gillies 2007). The popularity of authorship is demonstrated by the rising amount of individuals registering their profession as an author which increased to 1,673 from 626 between the censuses of 1841 and 1861 (Leary and Nash 2009). With the status of authors improving, here the window of opportunity opened more definitively for the literary agent.

In comparison to the author in the 1700 s and 1800 s, the nineteenth century author was recognised as the owner of their work due to the Copyright Act of 1814. Subsequently authors were able to benefit from the commercial value of their publications, as previously these rights were controlled by the publisher (Feather 2006). Consequently, the contractual negotiations between authors and publishers became increasingly complex as more ways to commercialise literature increased in popularity. Developments in copyright law prompted a different approach to selling literature, the commercial value was in the text as opposed to the physical publication format. Literature could be enjoyed as novels or in part publication serialised through magazines, and popular stories inspired dramatic adaptations. With each format the author could demand a share of these profits gained through what are now referred to as subsidiary rights usually payable by royalty. Publishing agreements became more sophisticated to cater for the increasing diversity of subsidiary rights, and negotiations could become in the words of popular Victorian novelist and Watt's first client George MacDonald (1824-1905) ‘time consuming' (F. W. 1892). 
Although legislation had changed, it took longer for the culture of the industry to change. It can be argued that this slow transformation in culture increased the opportunity for literary agents. Publishers held and still hold a pivotal and important position in the industry. They are the connection between the author and reader and in many cases were responsible for providing the capital for turning literature into a tangible and potentially lucrative commodity. In many cases Victorian fiction's triumphs were products of publishers rather than authors (Sutherland 2013: 1). This dominant position of the publisher had been created and reinforced by generations of family firms. However, the collective voice of authors was becoming stronger, pushing against the old traditions of the outright selling of copyrights, which did not entitle them to receive a share of future profits.

Outright copyright sales moved towards the half profits system between the 1830 s and 1860s, until it was eventually replaced by royalties in the late 1800s (Feather 2006). The half profits system would entail the publisher putting forward the initial capital for all production expenses (printing, binding, typesetting etc.), then once these costs were recovered from sales the profits would then be split equally between the publisher and the author (Feather 1994). Although prevalent, this system created tension between authors and publishers as in some instances it fostered distrust. Publishers were often accused of exaggerating their sales costs or diminishing sales in receipts provided to authors, therefore allowing them to keep a larger share of the profits (Feather 1994). For example, author Anthony Trollope (1815-1882) recounts in his autobiography that his first novels were published by half profits, and he commented that he received ' $£ 20$ down’2 on his new historical novel La Vendee (1850) (Trollope 1922: 69). Furthermore, he was to receive an additional $£ 30$ on the sale of 350 copies, and $£ 50$ if 450 copies were sold in six months. Yet after he received his initial payment of $£ 20$, he heard no

\footnotetext{
${ }^{2}$ This colloquial term would today be considered an advanced payment before a publication of a work.
} 
more from his publisher Henry Colburn (1784/5 - 1855) and he did not receive any accounts therefore could not query whether his novel had made any sales (Trollope 1922).

As some authors pushed against the established business practices which had enabled negotiations to be dominated by publishers. The Copyright Act of 1814 gave legal protection to authors, giving them a legal standing to oppose traditional business practices, adapting what could be considered as appropriate within the institutional context. Here the opportunity for literary agents emerges as some authors needed help to negotiate contracts and to be freed from what Sir Walter Besant referred to as 'the intolerable trouble of haggling and bargaining,' which created a demand for a 'middleman' in the publishing industry (Gillies 2007: 45). Exploring the historical context of the publishing industry prior to Watt starting his agency highlights the factors that enabled this relatively new literary business to flourish in an industry rooted in tradition.

\section{Authors: Early Adopters of New Practices}

Although the most notable, A. P. Watt was not the first literary agent, there were others operating at the same time as him, yet it was Watt's business model that endured. Alexander Macleod Burghes (flor. $19^{\text {th }}$ c.) has also been noted as one of Britain's earliest literary agents alongside Watt (Fritschner 1993). However, unlike Watt, Burghes did not immediately advertise himself as a literary agent instead he referred to himself as a publisher's accountant. There is only a small number of sources that document Burghes's movements as an agent, indeed all that is left of the company are the bankruptcy papers held at the National Archives in London. ${ }^{3}$ Others were also operating as literary agents at the same time as Watt, such as Charles M. Clark who registered himself as a literary agent at 40 Staple Inn, in the region of

\footnotetext{
${ }^{3}$ J. M. Burghes and Company Ltd. Incorporated in 1920. Dissolved between 1920 and 1932, National Archives.
} 
Chancery Lane in $1880 .{ }^{4}$ Furthermore James Hepburn in 2009 revisited his research on the literary agent, confirming that that there was others who listed themselves under 'Agency, Literary' in the Post Office Directory including, Stefan Poles and Thomas Vary Paterson (Hepburn 2009: 631 - 632).

The sources confirm that Watt was not alone in his venture yet he was innovative in how he professionalised the functions of the literary agent and consequently had a significant impact on the publishing industry. Identifying other agents operating in the late nineteenth century demonstrates that change within the institutional context was burgeoning, prompting the question as to why was Watt successful and how did he become legitimate in comparison to others? Mutch (2007) comments that more attention in research should be dedicated to exploring those who push for institutional change yet are unsuccessful, however in this context following this line of research is difficult as there are limited sources which confirm the movements of other actors during this time. Therefore, it is useful to explore Watt's push for change not as an isolated factor but as an extension of institutional change from others who may have had an influence on how he chose to do business, especially as the opportunity for change had emerged within the institutional context before Watt started his business.

It is apparent that Watt's career began in earnest after he moved to London and became familiar with the thriving publishing network in the capital when he took on the position of advertising agent at the publishing house owned by his brother-in-law Alexander Strahan (1833 - 1918). Watt's position enabled him to gain significant knowledge about the marketplace. He connected authors and literature to specific publication outlets, and consequently he made valuable contacts with editors and publishers. Although Strahan published prolific authors such as Anthony Trollope (1815 - 1882) and Lord Alfred Tennyson (1809 - 1892), due to financial

\footnotetext{
4 "Post Office London Directory, 1880 [Part 2: Commercial \& Professional 1 Directory]," (London: Kelly's Directories LTD, 1880), 782
} 
difficulties the company was declared bankrupt in 1882 (Srebrnik 2004). The demise of the Strahan publishing house had a direct effect on Watt's financial income, this pushed him to go independent and start his agency (Srebrnik 2004; Zinkhan 2006). Watt chose to enter selfemployment, utilising his knowledge of the industry and the contacts he made during his tenure at Strahan, and in 1879 Watt relinquished his duty as secretary of the company. ${ }^{5}$

The challenge was for Watt to transition from advertising agent to literary agent in an industry where the publisher was the dominant force in driving negotiations with authors. This accepted norm between authors and publishers had ensued for decades, however, as mentioned earlier industry dynamics were shifting. Developments in copyright law had provided authors with stronger bargaining power, and the opportunity was for Watt to provide a service. He could charge authors for counsel and advice, helping them to secure the best terms for their manuscripts, which for many authors was a welcome service (Caves 2002). Watt adapted the familiar form of the advertising agent who worked within a publishing house, to becoming an independent literary agent working on behalf of the author. Watt became 'institutionally innovative' by creating new processes that shifted how authors and publishers negotiated contracts (Deephouse, Bundy et al. 2018).

One of Watt's key contacts was author George MacDonald, a clergyman who had been regularly published in the periodicals owned by Strahan. Watt had handled all of the advertising of MacDonald's work to periodicals and publishers, and due to the close nature of their professional relationship a friendship ensued. Through their friendship, Watt knew that MacDonald was in need of someone to handle his negotiations with publishers, as it was a time consuming business, an aspect that Watt mentioned in an interview in literary magazine The Bookman (F. W. 1892). Watt seized this opportunity and MacDonald became his client in 1880. MacDonald could be viewed as Watt's first legitimacy evaluator (Bitektine and Haack 2015),

\footnotetext{
${ }^{5}$ Letter to the Reverend John in Oxford from Watt, $18^{\text {th }}$ October 1879; Letter \#2 Vol. II A. P. Watt \& Son (BC).
} 
as he agreed to be represented to publishers and the wider publishing industry by Watt as a literary agent as opposed to an advertising agent employed by the Strahan publishing house. MacDonald, a popular author conferring legitimacy aided Watt of gaining wider collective legitimacy by other authors.

Watt was used to receiving $10 \%$ commission for his work as this is what he had been earning whilst working as an advertising agent at Strahan (Gillies 2007). In a note written in 1879 Watt highlights that he had done a good job as he was able to sell a particular story 'expediently and at such a good price. ${ }^{6} \mathrm{He}$ finished the letter by mentioning to the recipient that they 'will not consider [his] commission of $10 \%$ on the sale to be too high. ${ }^{7}$ However from the correspondence of Watt, it is highlighted that he had to negotiate his commission charges with MacDonald. In a letter written to MacDonald on $18^{\text {th }}$ February 1880 , Watt writes:

'I am getting nothing from Strahan and Co. upon my commission as an advertising agent and every other business $[\mathrm{I}]^{8}$ get to do for my living. I now charge you something to the coin. I have lately sold his stories for well known authors for one of which I got $£ 250$ of which I received $10 \%$ for my work. But I should not think of, in this case, is charging you so much as this, but will have you to fix the amount. I shall be glad if you can place your advertising in my hands on your return to England."9

MacDonald's reply to Watt is not in the archive, however it can be assumed that MacDonald was not altogether happy at the prospect of paying Watt $10 \%$ commission. Watt wrote

\footnotetext{
${ }^{6}$ Letter dated $10^{\text {th }}$ November 1879 , no recipient stated; Letter \#13, Vol II A. P. Watt \& Son (BC)

7 ibid

${ }^{8}$ There was a smudge on the document here and I am assuming that the text reads 'I.'

${ }^{9}$ Letter to George MacDonald from Watt, $1^{\text {st }}$ March 1880; Letter \#170 Vol II. A. P. Watt \& Son (BC)
} 
MacDonald another letter in March 1880, in which he made a point of stating how time consuming the work was and it was the 'only way that [he] could earn his livelihood. ${ }^{10}$ Watt had to defend what he referred to as the 'highness of the charge' as 'there is a good deal of labour in the way of letter writing and now personal negotiation which of course takes time. ${ }^{11}$ In addition he mentions that 'recompense is fairly due' because of the 'knowledge and experience necessary before one can undertake such work.' ${ }^{12}$ This statement exhibits signs of professionalism as he is trading on the strength of his knowledge in order to position himself in the marketplace. Watt's commercially orientated approach to the business of being a literary agent is an aspect that aided the professionalisation of this previously informal author/friend relationship.

Despite defending how much work he did for his clients, as demonstrated in the letter, Watt was willing to concede his $10 \%$ commission in order to convince MacDonald to use him for representation. Watt states 'I can only repeat what I said in my last letter, that I should never think of asking you to pay me as much as $10 \%$ but will be content with half of that. ${ }^{13}$ MacDonald was a popular author who published regularly in leading periodicals, and as Watt had previous experience of selling MacDonald's publications he was familiar with the market and also the editors who would be willing to buy his stories (Sadler 2004). Watt used this strategy to his advantage as MacDonald agreed, and this professional relationship provided Watt with a firm foothold in the industry and early legitimacy. Watt did however charge his other clients $10 \%$ commission, for instance he negotiated the sale of one of Besant's titles which was sold to Longman for $£ 1300$ on $10 \%$ commission. ${ }^{14}$ In some cases Watt's commission charge was as high as $15 \%$ as documented in a letter to Richard Pryce in 1891, he

\footnotetext{
10 ibid

11 ibid

12 ibid

13 ibid

${ }^{14}$ Letter to Sir Walter Besant, $20^{\text {th }}$ July 1884; Vol II, A. P. Watt \& Son, (BC)
} 
charged $15 \%$ on sums under $£ 100$ and $10 \%$ on sums above that amount. ${ }^{15}$ Further letters in the archives of the A. P. Watt literary agency do not explicitly highlight whether Watt indeed did raise his commission charge with MacDonald to $10 \%$.

As demonstrated in the sources, there are multiple letters, memos and contracts which confirm that authors accepted Watt's business practices through a formalisation of procedures, which led him to be perceived as legitimate with authors. In addition, as Watt's client list grew, the formal procedures of payment through formalised contractual agreements were further embedded and accepted as this is the way that things are done; providing increased legitimacy not just to Watt but to his literary agency. In particular, Watt being recognised as MacDonald's literary agent, and later other popular authors including Sir Walter Besant and Rudyard Kipling (1865 - 1936) was an important juncture. Their employ of Watt conferred legitimacy as they were established authors exemplifying approval to his business practices, as if a successful author used an agent it could then be perceived by new entrants to the industry as a necessity for ensuring commissions. Authors accepted Watt's way of doing business, and as their adoption of using his formal procedures became more widespread, Watt and his agency gained increased legitimacy. Although Watt had authors on his side, he also needed the publishers to accept his role in the production process of literature. One mechanism that Watt used which enabled him to gain further legitimacy was the agency clause; an aspect explored in the next section.

\section{The Agency Clause: A Pathway to Legitimacy}

The process of legitimacy building in regards to publishers was more complex in comparison to authors. Informal relationships between authors, their advisors and publishers were being replaced with formal contracts. On becoming a literary agent Watt had a bank of contacts and

\footnotetext{
${ }^{15}$ Letter to Richard Pryce, $1^{\text {st }}$ April 1891; Letter \#39, Vol XXV, A. P. Watt \& Son (BC)
} 
relationships with most publishers and their houses, but they had known him as an advertising agent. Consequently, Watt needed to be strategic with his legitimation activities as he needed to build legitimacy as a literary agent. The legitimacy he had been gaining from authors was paramount, as their increasing acceptance was supporting Watt's standing with publishers. Contracts and letters of agreement in various archives present a wealth of evidence that illustrates how Watt used contract law as a mechanism of achieving acceptance and subsequently legitimacy from publishers. The clauses and language used in these contracts documents the change in accepted practices, as certain clauses reoccur over a period of time in multiple contracts. In his comprehensive history of the publishing industry John Feather confirms that readers were operating from around 1830, although 'their emergence as employees of authors or paid agents of publishers is obscure' (Feather 2006: 139). Therefore, it is difficult to distinguish the boundaries between paid agent and friendly service. Furthermore, tracing their involvement in the negotiation process is also difficult, as readers were not formally recognised on publishing agreements. Using contracts to formalise the relationship between authors, literary agents and publishers was a legitimation activity which provided a level of appropriateness to the literary agency, allowing for new business practices to form.

The breakdown of communication between author and publisher was crucial in building legitimacy for Watt's agency, what Gillies (2007: 26) refers to as the 'destabilisation of the author-publisher dyad' which became replaced by 'the author-agent-publisher triad.' The relations between author and publisher had been a two-way process for generations, stretching back to transactions in the sixteenth century between either author and patron, or author and bookseller who at the time held the same function as what is recognised today as the publisher (Feather 2006). Initially Watt operated in the same manner as he had done as an advertising agent, he was paid by the author after they had received their fee or royalties from the publisher. 
Watt being paid in this fashion after he became a literary agent demonstrates that the institutional culture of the informal operation between readers and authors was still prevalent. The letters in the archive show how Watt used different methods of charging his customers including different commission rates according to the price of a work sold, also charging flat fees. This aspect of Watt's business is rarely discussed in studies on his literary agency, it highlights the change of a previously informal service to authors agreeing for his commission to be deducted from their royalties. If the previous method of payment had continued, there may not have been such a divergent shift as the transactions between the author and publisher may not have significantly changed. It was the agent interrupting the flow of communication between these two parties that challenged accepted practices, causing a new way of doing business to flourish.

The sources in the archive of the A. P. Watt literary agency portray that the catalyst for change was the slow payment Watt received from his first client George MacDonald. In some cases, it was months after the work had been completed that Watt would receive payment, which led to Watt formally writing to MacDonald and ask for payments to be sent by a specified date. This did not spur MacDonald to pay on time, so Watt requested for payments to come through his office first to ensure a regular cash flow. ${ }^{16}$ This would entail the publisher to deal with agent and no longer the author, a conscious decision by Watt to ensure survival to his agency, although a by-product of this action would cause disruption in the industry.

Publishers were not used to dealing formally with an intermediary. Publisher William Heinemann (1863-1920) was one of the most vocal protesters against the burgeoning popularity of the literary agent, referring to them in the newspaper press as 'parasites,' and 'unscrupulous opportunists' (Heinemann 1893: 663). Leading up to Watt's emergence in the industry, publishers were used to dealing informally with the author's reader or the author

\footnotetext{
${ }^{16}$ Letter to MacDonald, $24^{\text {th }}$ June 1880 , Letter \#374, Vol. II A. P. Watt \& Son (BC).
} 
themselves. Subsequently, it is likely that the relational dynamic may have been different from how they may have approached negotiations with literary agents. Watt's professional presence forced transparency between publishers and authors, causing a shift in power between these parties. Heinemann's public condemnation of literary agents is one of the few cases that is evidence of resistance to Watt's pathway to legitimacy. Heinemann was unsuccessful in blocking the growing significance of the literary agency, primarily as most publishers could see the value in having an intermediary who provided the job-matching function for them; an aspect Caves (2002) argues reduced the publishers costs in finding new manuscripts. Later, agents including Watt worked on behalf publishers, as agents could potentially save editors much time and money by sourcing new articles or books to commission (Gilles 2007). Watt was fortunate to have been given legitimacy early on by authors who had significant bargaining power with publishers. If Watt had represented new authors or those without significant sociocultural capital, publishers may not have been as easily swayed to agree to the disruption and emergence of this middleman.

Watt embedded himself and his agency into a favourable position by ensuring that authors and publishers did not negotiate between themselves or undertake any financial agreements or manuscript transactions; the disruption that Heinemann was pushing against. All correspondence and royalty cheques came through the agency and Watt would disburse the payments to his clients, minus his commission. This was a benefit to authors, as correspondence and accounting for payments were kept centralised, as many authors submitted their work to a range of publishers and periodicals. However, Heinemann vehemently argued that the literary agent (referring to Watt although he does not mention him by name) 'ha[d] broken the link between businessman and artist, and ha[d] created friction and disloyalty between seller and buyer' (Heinemann 1893: 663). Heinemann believed in the chivalrous approach to business, that transactions should be undertaken between two parties without the need for a middleman. 
The tone of his article echoes the traditional ideal of publishing that was rapidly becoming outdated. Despite Heinemann's public condemnation of literary agents, authors found that their services were much required, especially to those who were inexperienced when it came to negotiations.

Watt had been operating as an agent for around a decade, when in 1889 he insisted that authors and playwrights signed a formal agreement that gave him the legal power to handle all their contracts. ${ }^{17}$ This was fundamental to Watt establishing a legitimate place in the industry, as he was given the autonomy to act for his clients, therefore could challenge any opposition from publishers. Watt was able to push forward his business practices as using contract law an accepted institutional framework - demonstrated to publishers that he was operating within a legitimate structure. This was a significant turning point for Watt and his agency. Authors had agreed to a formal payment process, a change from the informal relationship many had with the author's reader. In addition, by authors agreeing to legally grant authority to Watt to handle the negotiation and administration of their copyrights, authors were demonstrating approval to a relatively new entrant to the industry.

Communication between author and publisher was broken down through contracts, in particular through what I refer to as the agency clause. The clause was constructed in a way that made it difficult for publishers to challenge Watt's authority in the business transaction. Usually the clause reads, 'the said [author's name] hereby authorises and empowers his Agents Messrs A. P. Watt... to collect and receive all monies under the terms of agreement... and to act generally in all matters in any way regarding the said agreement. ${ }^{, 18}$ Similar worded clauses are now standard on most contracts between and publishing houses, in addition they also insist that publishers will communicate with an author through their agent (Jones and Benson 2016).

\footnotetext{
${ }^{17}$ For example, see Agreement between Watt and Harold McCunn, 30 ${ }^{\text {th }}$ April 1889, Folder 4.3 A. P. Watt (UNC).

${ }^{18}$ Agreement between Watt and Rudyard Kipling, giving Watt power of attorney and to act as Kipling's agent, 13th August 1891; Folder 452.53/4, A. P. Watt (UNC)
} 
An example of being Watt institutionally innovative was how he made use of contract law to his advantage. He utilised what are now often to referred to as 'boilerplate clauses' which are generally used on commercial contracts (Cordero-Moss 2011: 49). These clauses use standard language that provide 'general applicability' (Cordero-Moss 2011: 49) or 'standardised provisions' in a contract, explaining to parties how to govern their relationship (Stark 2003: 5). These clauses, due to the repetition across multiple contracts Stark (2003: 6) argues allows them to 'garner a hallowed status as time passes' which can lead to the clauses being easily glossed over. As Watt's client list grew, and the circulation of this standardised wording was accepted by multiple publishers, the agency clause became a recognised and legitimised feature on the publishing agreement. This was a crucial juncture for Watt to be perceived as legitimate by publishers. By agreeing to representation by Watt and for the agency clause to be included on publishing agreements, authors as legitimacy evaluators were demonstrating that they conferred legitimacy to Watt. Consequently, publishers were pushed to accept Watt's position, otherwise they may lose out on commissions from leading authors. The agency clause could be viewed as the second stage in gaining legitimacy from publishers. The introduction of these contracts between publishers, Watt and authors became a 'tipping point' for the literary agency to move from a space of being challenged to being perceived as legitimate by two collective sets of legitimacy evaluators in the publishing industry.

Analysing letters of attorney and contracts demonstrates the interplay between institutional contexts and organizations. By the late nineteenth century, the institutional culture of the publishing industry was still shifting, highlighted by the emergence of several professional bodies which sought to represent the interest of its members in the wider environment including the Society of Authors (1884) and the Publishers' Association (1896). The relationship between authors and publishers at the time was adapting, therefore the role of the literary agent had to also adapt in order to best address the opportunities in the industry. 
Watt being embedded in the industry worked to his advantage, he was best placed to understand how his agency could make use of the opportunities provided by the shifting interorganizational relationship between authors and publishers.

Using contractual documents which were similar in tone to what publishers had been using on their agreements with authors aligned Watt's practice with an established set of processes, consequently making the legitimacy process more amenable to existing organizations. It was not something innovative to the industry, however the adaptation of the practice is that the literary agent was authorised to negotiate on behalf of the author. As discussed above, authors had been using readers and receiving a similar service, yet there is little evidence to show that authors had formal contracts with their readers. The practices of the literary agent became a fusion of the normative processes of how authors and publishers had been operating for decades, which allowed literary agents to be perceived as legitimate with less resistance from established organizations.

In many cases, Watt used pre-printed memorandums. The author was required to enter their name and the company that Watt would be representing the author to, as well as sign and date the document; however, these memos were not explicit in outlining precisely what the activities were. ${ }^{19}$ They had the same function as an agreement as they provided written consent for Watt to act on an author's behalf. Many publishers used pre-printed contracts that were a few pages long, explicitly detailing the nature of their agreement with a client (whether that be an author or another publisher). ${ }^{20}$ Spaces were left for details pertaining to the specifics of the contract to be entered, such as the name of the author and the title of publication; this method of contractual arrangements may have influenced Watt to use the pre-printed memorandums.

\footnotetext{
${ }^{19}$ Agreement between Watt and Harold McCunn, 30th April 1889, Folder 4.3 A. P. Watt (UNC)

${ }^{20}$ For example, Watt acted on behalf of Chatto \& Windus in the purchase of copyrights from Richard Bentley and Watt had signed a pre-printed contract; Agreement dated $8^{\text {th }}$ February 1886, Add MS 46622, Bentley Papers, BL.
} 
These memos were short, only a few lines long and did not require to be witnessed or notarised, which highlights that Watt would have used these agreements primarily as a measure of authority to the publishers he negotiated with, as well as for protection and to lower the risk of misunderstandings between Watt and his clients. Although Watt required these to be signed, in 1891 author Rudyard Kipling had a specific agreement drawn up between himself and Watt that detailed the exact terms of their professional relationship. ${ }^{21}$ This document was witnessed, notarised and signed by both Watt and Kipling, confirming that this contract would be legally binding and ensured protection for Kipling and - as he refers to it in the contract - his 'literary property.' 22 These memos further demonstrate how authors as a collective were legitimacy evaluators. The organizational process of documenting a formal relationship between authors and Watt and could be viewed as a point at which legitimacy occurred. In conjunction with the agency clause on publishing agreements, these contractual documents are evidence of legitimacy and demonstrate the point at which legitimacy is conferred to an organization, highlighting the foundation for new organizational processes in the publishing industry.

In addition to the agency clause, one of the most important aspects that cemented the position of the literary agent into the wider publishing industry was the endorsement agents received by the President of the Society of Authors Sir Walter Besant. An active lobbyist for copyright reform, Besant had been vocal in support of literary agents. His editor James Rice (1844 - 1882) had performed similar duties to an agent from 1869 to his death, as Besant was 'extremely averse' to making business terms for publication for himself (Besant 1902: 187188). Watt later became Besant's agent in 1883 and subsequently was nominated to act as the agent of choice on behalf of the Society of Authors. This endorsement was a factor that significantly helped to give Watt further legitimacy. Besant had publicly argued that authors

\footnotetext{
${ }^{21}$ Agreement between Watt and Rudyard Kipling, giving Watt power of attorney and to act as Kipling's agent, $13^{\text {th }}$ August 1891; Folder 452.53/4, A. P. Watt (UNC).

22 ibid, the agreement was witnessed by James Brookes.
} 
should not shy away from the commercialisation of literature, and should not be afraid to be compensated for their work. ${ }^{23}$ Although Watt declined the offer, Besant continued to recommend his services to the members of the society, providing a seal of approval to Watt and literary agents in general. ${ }^{24}$

\section{Conclusion}

The literary agent is a recent addition to the publishing industry, yet in a relatively short space of time this service became an instrumental part of the publishing industry. Progressing from being an outsider and in some cases despised by some publishers, to becoming a gatekeeper, as all communications, agreements and negotiations often went through the office of the agent. Doing business in this way, became accepted within the institutional context of the publishing industry as agents overtook the previously informal service of the authors' reader. By the late nineteenth century, many authors saw literary agents as an invaluable asset providing them with feedback to the commercial strength of their literature and in some cases handling the negotiations with publishers. It is now very difficult for an author to approach a publisher without representation of an agent, especially as boilerplate agreements which feature the agency clause are today used by most publishing houses (Clark and Phillips 2014; Jones and Benson 2016).

This paper has explored the development of the literary agent, demonstrating the mechanisms that triggered institutional change in the publishing industry. It argued how formalising the service between authors and agents, and the introduction of the agency clause allowed Watt to be perceived as legitimate. Drawing on letters and contracts from the business archive of the A. P. Watt literary agency, this paper has demonstrated the strategic use of

\footnotetext{
${ }^{23}$ From Sir Walter Besant's Speech at the 1892 AGM of the Society of Authors, MS 56869, Society of Authors Archive, BL, 13

${ }^{24}$ Meeting from 14th February 1887 referenced in Sir Walter Besant's Speech at the 1892 AGM of the Society of Authors, MS 56869, Society of Authors Archive, BL, 115
} 
contract law - a legitimised and socially accepted structure - as a mechanism to gain legitimacy and limit resistance from established organizations. Understanding how new practices took root through the acceptance of the literary agent's formal role in the negotiation process, highlights why Watt was successful in disrupting an industry that was operating with practices that had endured for generations. Furthermore, exploring the processes of legitimacy between authors, literary agents and publishers brings further understanding of the changing dynamics between organizations in the publishing industry.

Firstly, by authors - in particular George MacDonald - agreeing to Watt as an authority empowered to negotiate on their behalf highlights the point at which legitimacy was first conferred. As Watt's client list grew, more authors agreed to the formalisation of business practices therefore adopting and legitimising the process, causing legitimacy to spread among authors as a collective set of legitimacy evaluators. Using contracts to formally empower the literary agency also displayed authority to publishers, decreasing their ability to push against Watt's position in the negotiating process. Therefore, publishers secondly became legitimacy evaluators as they had to also agree to the literary agent being a part of the negotiation process. Their acceptance further conferred legitimacy, subsequently when later agents emerged operating in a similar fashion, this new way of doing business became further rooted into the industry.

This paper contributes to the growing literature which combines historical research with institutional theory, going back inside the organization to connect some of practices at the individual and organizational levels which consequently can prompt a larger shift in an industry (Suddaby and Viale 2011; Bitektine and Haack 2015; Micelotta, Lounsbury et al. 2017; Decker, Üsdiken et al. 2018). The paper brings to the foreground part of the institutional story of the publishing industry, by drawing on sources which explicitly identified the beginnings of new processes that are now so embedded in the publishing industry, it is a widely accepted 
business practice. Analysing the sources for evidence of legitimation processes demonstrates the links between the individual (Watt), the organization (the literary agency) and the wider environment (the publishing industry), highlighting how 'organizations strategically shape their institutional contexts to further their own individual ends' (Marquis and Raynard 2015: 295).

Returning to Caves' (2002) comments, although Watt received some resistance the sources highlight that Watt had carved a space for literary agents in the nineteenth century, later working for both authors and publishers. Therefore, the paper has demonstrated that between Watt opening his literary agency circa 1875 and 1884 when he was asked to be the official literary agent of the Society of Authors, the legitimacy of this newcomer had significantly risen. The dynamic changes in the literary marketplace provided more opportunities for authors and publishers to offer literary products. Advances in copyright law had created an opportunity for a 'middleman' in contractual negotiations, igniting a mutual interdependence between authors, agents and publishers, which has become a common feature within the publishing industry that is still evident today (Gillies 2007). Therefore 'matchmaking' between these parties was a growing need, so agents were no longer 'shunned' instead embarked on a path to become an integral part of the publishing industry

By 1900, Watt was perceived by established organizations in the publishing industry as legitimate along with his business practices which became the 'blueprint' for the second wave of literary agents. These included James Brand Pinker (1863 - 1922) whose agency folded in the mid-1930s (Gillies 2007), and Curtis Brown (1906-1980) who founded in 1899 one of today's leading international literary and talent agencies. The increased complexities of negotiating commercial contracts created a space for literary agents in the nineteenth century. Consequently, the benefits of working with an intermediary were recognised, changing the literary marketplace and how publications were commissioned and sold. As a more formal way 
of doing business became commonplace, the behaviour took root leading to the incorporation of literary agents and similar businesses to become key organizations in the contemporary creative industries.

\section{References}

\section{A Note on Archival Sources}

Documentary sources from archives are referenced throughout this paper. I have cited the item in the footnotes with an abbreviated reference to the archive in which they are held. Where possible I have used the citation for the archive provided by the holding organization. Below are the full details of the archive collections cited:

- A. P. Watt and Son Records, 1861-1971 bulk (1880-1949), Berg Collection of English and American Literature, New York Public Library (cited in the footnotes as A. P. Watt $\&$ Son $[B C])$.

- A. P. Watt Records \#11036, Rare Book Literary and Historical Papers, The Wilson Library, University of North Carolina at Chapel Hill (cited in the footnotes as A. P. Watt [UNC]).

- Company No: 166272; J M Burghes and Company Ltd. Incorporated in 1920. Dissolved between 1920 and 1932, BT 31/25797/166272, National Archives, Kew, (cited in footnotes as National Archives, Kew).

- Some sources were consulted at the British Library, the full reference is Archives and Manuscripts, British Library, London, (cited in footnotes as [item location, collection name,], BL).

\section{Sources}

Aldrich, H. E. and C. M. Fiol (1994). "Fools Rush In? The Institutional Context of Industry Creation." Academy of Management Review 19(4): 645-670. 
Alvesson, M. and K. Sköldberg (2009). Reflexive Methodology: New Vistas for Qualitative Research. London, SAGE.

Assenova, V. A. and O. Sorenson (2017). "Legitimacy and the Benefits of Firm Formalization." Organization Science 28(5): 804-818.

Battilana, J., B. Leca, and E. Boxenbaum. (2009). "How Actors Change Institutions: Towards a Theory of Institutional Entrepreneurship " The Academy of Management Annals 3(1): 65107.

Besant, W. (1902). Autobiography of Sir Walter Besant. [S.1.], Hutchinson. Bilton, C. (2017). The Disappearing Product: Marketing and Markets in the Creative Industries. Cheltenham, Edward Elgar. Bitektine, A. and P. Haack (2015). "The "Macro" and the "Micro" of Legitimacy: Toward a Multilevel Theory of the Legitimacy Process." Academy of Management Review 40(1): 49-75.

Castelló, I., M. Etter, and F. A. Nielsen. (2016). "Strategies of Legitimacy Through Social Media: The Networked Strategy." Journal of Management Studies 53(3): 402-432.

Caves, R. E. (2002). Creative Industries: Contracts between art and commerce. Cambridge, London, Harvard University Press.

Clark, G. N. and A. Phillips (2014). Inside Book Publishing. London; New York, Routledge.

Cordero-Moss, G. (2011). Contract Models and Choice of Law. Boilerplate Clauses, International Commercial Contracts and the Applicable Law. G. Cordero-Moss. Cambridge, Cambridge University Press.

Cottenet, C. (2017). Literary Agents in the Transatlantic Book Trade: American Fiction, French Rights and the Hoffman Agency Abingdon. Abingdon, Taylor \& Francis.

Davies, J. A. (1983). John Forster: A Literary Life. Leicester, Leicester: Leicester University Press.

DCMS. (2016). "Creative Industries worth almost $£ 10$ million an hour to economy." Retrieved 17 November 2017, from https://www.gov.uk/government/news/creative-industries-worthalmost10-million-an-hour-to-economy.

DCMS and T. R. H. K. Bradley. (2017). "Creative industries' record contribution to UK economy " Retrieved 22nd May 2018, 2018, from https://www.gov.uk/government/news/creative-industries-record-contribution-to-ukeconomy.

Decker, S., B. Üsdiken, L. Engwall and M. Rowlinson. (2018). "Special issue introduction: Historical research on institutional change." Business History 60(5): 613-627.

Deephouse, D. L., J. Bundy, L. Plunkett Tost and M. Suchman. (2018). Organizational Legitimacy: Six Key Questions. The SAGE Handbook of Organizational Institutionalism. R. Greenwood, C. Oliver, T. B. Lawrence and R. E. Meyer. London, Sage.

Deephouse, D. L. and M. Suchman (2013). Legitimacy in Organizational Institutionalism The SAGE Handbook of Organizational Institutionalism R. Greenwood, C. Oliver, K. Sahlin and R. Suddaby. London, Sage Publications.

DiMaggio, P. J. and W. W. Powell (1983). "The Iron Cage Revisited: Institutional Isomorphism and Collective Rationality in Organizational Fields." American Sociological Review 48: 147-160.

Eliot, S. (2012). The Business of Victorian Publishing. The Cambridge Companion to The Victorian Novel. D. David. Cambridge, Cambridge University Press.

F. W. (1892). An Interview with Mr A. P. Watt. The Bookman. London. October: 20-22.

Feather, J. (1994). Publishing, Piracy and Politics: An Historical Study of Copyright in Britain. London, Mansell.

Feather, J. (2006). A History of British Publishing. London, Routledge.

Finkelstein, D. and A. McCleery (2013). An Introduction to Book History. London, New York, Routledge. Fritschner, L. (1993). Literary Agents and Literary Traditions: The Role of the 
Philistine. Paying the piper: causes and consequences of art patronage. J. H. Balfe. Urbana, Ill., University of Illinois Press. Fowler Wright, S. (2012). The Life of Sir Walter Scott: A Biography, Cabin John, Marylande, Wildside Press LLC.

Gillies, M. (1993). "A. P. Watt, Literary Agent." Publishing Research Quarterly 9(1): 20-33. Gillies, M. A. (2007). The Professional Literary Agent in Britain, 1880-1920. Toronto; London, University of Toronto Press.

Hampel, C. E. and P. Tracey (2016). "How Organizations Move From Stigma to Legitimacy: The Case of Cook's Travel Agency in Victorian Britain." Academy of Management Journal.

Heinemann, W. (1893). The Middleman as Viewed by a Publisher. The Athenaeum. London. 3446. Hepburn, J. (1968). The Author's Empty Purse and the Rise of the Literary Agent. London, Oxford University Press.

Hepburn, J. (2009). 'The Author's Empty Purse Revisited.” Sewanee Review. 117(4): 628640. Hesmondhalgh, D. (2013). The Cultural Industries. London, Sage Publications. Howkins, J. (2013). The Creative Economy: How People Make Money From Ideas. London, Penguin.

Jones, H. and C. Benson (2016). Publishing Law. London, Routledge.

Kipping, M., R. D. Wadhwani, and M. Bucheli. (2013). Analyzing and Interpreting Historical Sources: A Basic Methodology. Organizations in Time: History, Theory, Methods. M. Bucheli and R. D. Wadhwani. Oxford, Oxford University Press.

Kung, L. (2014). Leading for creativity in turbulent times. Handbook of Management and Creativity C. Bilton and S. Cummings. Cheltenham Edward Elgar.

Lawrence, T., R. Suddaby, and B. Leca. (2011). "Institutional Work: Refocusing Institutional Studies of Organization." Journal of Management Inquiry 20(1): 52-28.

Leary, P. and A. Nash (2009). Authorship. The Cambridge History of the Book in Britain 1830-1914. D. McKitterick. Cambridge, Cambridge University Press. VI.

Maclean, M., C. Harvey, and S. R. Clegg. (2016). "Conceptualizing Historical Organization Studies." Academy of Management Review 41(4): 609-632.

Marquis, C. and M. Raynard (2015). "Institutional Strategies in Emerging Markets." The Academy of Management Annals 9(1): 291-335.

Meyer, J. W. and B. Rowan (1977). "Institutionalized Organizations: Formal Structure as Myth and Ceremony." The American Journal of Sociology 83(2): 340-363.

Micelotta, E., M. Lounsbury, and R. Greenwood (2017). "Pathways of Institutional Change: An Integrative Review and Research Agenda." Journal of Management 43(6): 1885-1910.

Mutch, A. (2007). "Reflexivity and the Institutional Entrepreneur: A Historical Exploration " Organization Studies 28(7): 1123-1140.

North, D. C. (1990). Institutions, Institutional Chance and Economic Performance. Cambridge, Cambridge University Press.

Powell, W. W. and J. A. Colyvas (2008). The New Institutionalism. The International Encyclopedia of Organization Studies. S. Clegg and J. R. Bailey, London, Sage Publication Inc.

Rubinstein, H. (1975). A. P. Watt: The First Hundred Years. London, The Bookseller.

Sadler, G. E. (2004). MacDonald, George (1824-1905). Oxford Dictionary of National Biography. Oxford, Oxford University Press.

Scott, S. W. (1831). Autobiography of Sir Walter Scott, Bart. Philadelphia, Carey \& Lea.

Seppälä, J. (2017). "Managing the paradox of unwanted efficiency: The symbolic legitimation of the hypermarket format in Finland, 1960-1975." Business History 60(5): 699-727.

Srebrnik, P. T. (1986). Alexander Strahan, Victorian publisher. Ann Arbor, University of Michigan Press. Stark, T. L. (2003). Negotiating and Drafting Contract Boilerplate. New York, ALM Publishing.

Suchman, M. C. (1995). "Managing legitimacy: Strategic and institutional approaches." Academy of Management Review 20: 571-610. 
Suddaby, R. (2010). "Challenges for Institutional Theory." Journal of Management Inquiry 19(1): 14-20.

Suddaby, R., A. Bitektine, and P. Haack. (2017). "Legitimacy." Academy of Management Annals 11(1): $451-478$.

Suddaby, R., K. D. Elsbach, R. Greenwood, J. W., Meyer and T. B. Zilber. (2010). "Organizations and Their Institutional Environments - Bringing Meaning, Values and Culture Back In: Introduction to the Special Research Forum." Academy of Management 53(6): 12341240.

Suddaby, R., W. M. Foster, and A. J. Mills. (2014). Historical Institutionalism Organizations in Time: History, Theory, Methods M. Bucheli and R. D. Wadhwani. Oxford, Oxford University Press.

Suddaby, R. and R. Greenwood (2005). "Rhetorical Strategies of Legitimacy." Administrative Science Quarterly 50: 35-67.

Suddaby, R. and T. Viale (2011). "Professionals and field-level change: Institutional work and the professional project." Current Sociology 59(4): 423-442.

Sutherland, J. A. (2013). Victorian Novelists and Publishers. London, Bloomsbury.

Trollope, A. (1922). Autobiography. New York, Dodd, Mead and Company

Wadhwani, R. D. and M. Bucheli (2013). The Future of the Past in Management and Organization Studies Organizations in Time: History, Theory, Methods. M. Bucheli and R. D. Wadhwani. Oxford, Oxford University Press.

Watt, A. P. (1896). Letters to A. P. Watt. London, A.P. Watt \& Son.

Zinkhan, E. J. (2006). Watt, Alexander Pollock (1838-1914). Oxford Dictionary of National Biography. Oxford, University Press. 